\title{
Effect of Temperature, Time, and Material Thickness on the Dehydration Process of Tomato
}

\author{
A. F. K. Correia, ${ }^{1,2}$ A. C. Loro, ${ }^{1,3}$ S. Zanatta, ${ }^{1,3}$ M. H. F. Spoto, ${ }^{1,2}$ and T. M. F. S. Vieira ${ }^{2}$ \\ ${ }^{1}$ Fruits and Vegetables Laboratory, Department of Agroindustry, Food and Nutrition, University of São Paulo, \\ 13418900 Piracicaba, SP, Brazil \\ ${ }^{2}$ College of Agriculture "Luiz de Queiroz", University of São Paulo, 13418900 Piracicaba, SP, Brazil \\ ${ }^{3}$ Center of Nuclear Energy in Agriculture, University of São Paulo, 13400970 Piracicaba, SP, Brazil
}

Correspondence should be addressed to M. H. F. Spoto; martaspoto@usp.br

Received 3 March 2015; Accepted 31 May 2015

Academic Editor: Elad Tako

Copyright (C) 2015 A. F. K. Correia et al. This is an open access article distributed under the Creative Commons Attribution License, which permits unrestricted use, distribution, and reproduction in any medium, provided the original work is properly cited.

This study aimed to evaluate the effects of temperature, time, and thickness of tomatoes fruits during adiabatic drying process. Dehydration, a simple and inexpensive process compared to other conservation methods, is widely used in the food industry in order to ensure a long shelf life for the product due to the low water activity. This study aimed to obtain the best processing conditions to avoid losses and keep product quality. Factorial design and surface response methodology were applied to fit predictive mathematical models. In the dehydration of tomatoes through the adiabatic process, temperature, time, and sample thickness, which greatly contribute to the physicochemical and sensory characteristics of the final product, were evaluated. The optimum drying conditions were $60^{\circ} \mathrm{C}$ with the lowest thickness level and shorter time.

\section{Introduction}

The tomato, one of the most scientifically investigated vegetables because of its commercial importance [1], is highly perishable; and postharvesting losses reach 25 to $50 \%$. In tropical countries, there is a loss of $20-50 \%$, from harvesting to consumption [2-5]. Tomato fruit presents high water content, 93-95\% [6]. It is low in calories and rich in vitamins $\mathrm{A}, \mathrm{C}$, and $\mathrm{E}$ and minerals such as calcium, potassium, and phosphorus. In a rank of 10 vitamins and minerals, tomato is the first in terms of contribution in the diet $[7,8]$.

Brazil is the largest tomato producer in South America, followed by Chile and Argentina. Northeastern region (Pernambuco and Bahia states) accounted for $46 \%$ of the production, São Paulo State 30\%, and the Cerrado region (Goiás and Minas Gerais states) 24\% [9-11].

Drying process consists of the transfer of a fluid in a solid to a nonsaturated gaseous stage [12]. The dehydration in foam layer, lyophilization, drying in a traditional oven and vacuum, and sun drying are among the most widely used methods to process the tomato [13-15]. The removal of moisture must be accomplished in a manner that will be least detrimental to the product quality. Several dehydration processes have been developed to maximize the use of the available conditions for the raw material as well as the energy source used [16]. The dehydration of products stands out as a method to maintain the desired quality for prolonged periods $[17,18]$. In addition, drying is a classical method of food preservation; however, due to undesirable changes in quality of dried product pretreatments and drying conditions, studies are necessary [19]. In Brazil, the interest in studies that investigate tomato drying processes is recent, and the dried tomato arrived in the Brazilian market from other countries, namely, Spain and Italy $[20,21]$.

The consumer's demand for tomato products has increased in recent years [22]. It is increasing rapidly both in domestic and in international markets with major portion of it being used for preparation of convenience food [23]. Tomato and their derivatives are rich in antioxidants and can be considered an important source of carotenoids (lycopene), ascorbic acid, and phenolic compounds [7, 8]. Moreover, the heat increases the bioavailability of lycopene, which is 


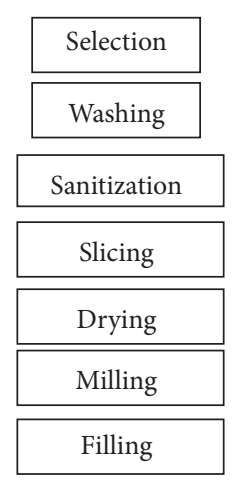

FIGURE 1: Flowchart of the dehydration process of the tomato.

better absorbed by the body when the tomato is cooked, thus, ideal for the consumption of tomato sauces and soups. The industrialization process of the tomato shows that the preparation of sauces, ketchup and others does not destroy lycopene [24-28].

This study evaluated the effects of temperature, time, and thickness of tomatoes slices during the drying process. A central composite design of two and three factorial was applied to investigate the yield.

\section{Materials and Methods}

2.1. Dehydration. To investigate the influence of variables on the dehydration of tomatoes, tomato type Carmen cv. (long life) was used. Experiments were conducted using a drying hanger with electric heating, with temperatures ranging between 40 and $80^{\circ} \mathrm{C}$, containing 10 perforated trays. The drying hanger has an automatic control of temperature by a digital thermostat coupled with electrical resistance, for automatic temperature stabilization in the cabin of the dryer and forced convection, depending on the air circulation speed of $1.5 \mathrm{~m} / \mathrm{s}$. The experiment was conducted in the Food Engineering Laboratory of the Methodist University of Piracicaba (UNIMEP).

The variables of the drying process of the tomato were the temperature $\left({ }^{\circ} \mathrm{C}\right)$, time $(\mathrm{h})$, and thickness $(\mathrm{mm})$. The dehydration process of the tomato is shown in Figure 1.

Nearly $1.5 \mathrm{~kg}$ of tomatoes was selected which were purchased from the local town market selected according to size, weight, color, strength, and firmness in order to obtain uniformity in the samples. They were washed and soaked for $15 \mathrm{~min}$ in an aqueous solution containing $0.2 \mathrm{~mL} \cdot \mathrm{L}^{-1}$ sanitizer (sodium hypochlorite $2.5 \%$ ) and were cut into slices with a thickness of $10 \mathrm{~mm}, 12.9 \mathrm{~mm}, 20 \mathrm{~mm}, 27.1 \mathrm{~mm}$, and $30 \mathrm{~mm}$ using an industrial slicer, Skymsen PAE-N, which is made of stainless steel and a slicing disc and allows you to set the height, enabling continuous and homogeneous slicing.

Afterwards, the slices were accommodated in trays and placed in a dryer at different temperatures $\left(50^{\circ} \mathrm{C}, 52.9^{\circ} \mathrm{C}\right.$, $60^{\circ} \mathrm{C}, 67.0^{\circ} \mathrm{C}$, and $70^{\circ} \mathrm{C}$ ) until the final product obtains moisture smaller than $10 \%$ because oxidation and browning reactions are the major causes of degradation of dried and intermediate moisture foods [29-31]. Tomatoes have a limited shelf life at ambient conditions and are highly perishable, as previously cited [23]. The estimate of the final product mass was calculated according to the known variables of the initial weight of the product before putting it in the oven and the initial moisture content of the product, according to (1) used by Camargo [21]:

$$
M_{f}=M_{i}-\frac{100-U_{i}}{100-U_{f}}
$$

where $M_{f}=$ final mass of the dried product $(\mathrm{g}), M_{i}=$ initial mass, $U_{i}=$ initial moisture of the product (\% wet basis), $U_{f}=$ final moisture of the product (\% wet basis).

The moisture content of the product was determined by a vacuum oven, Marconi MA-30, at a temperature of $70^{\circ} \mathrm{C}$ until the sample reaches constant weight. The product powder was placed in a container of 1.4-micrometer thickness and thermosealed containing approximately $50 \mathrm{~g}$ of the product in each package. The samples were kept at $25^{\circ} \mathrm{C} \pm 1$ and relative humidity of $60 \% \pm 2$.

2.2. Factorial Statistical Design. The fresh tomato dehydration processing was performed under different treatments with combinations in thicknesses of tomatoes and dehydration temperature, applying three replicates for each treatment and using the results from averages of repetitions to calculation effect.

During the dehydration process, the loss of product mass by comparing weights of the initial and final volumes in terms of drying time established for $10 \mathrm{~h}, 15 \mathrm{~h}$ and $50 \mathrm{~min}, 30 \mathrm{~h}, 44 \mathrm{~h}$ and $10 \mathrm{~min}$, and $50 \mathrm{~h}$ was measured.

The statistical design of the experiment followed the complete factorial designs $2^{2}$ and $2^{3}$ (for two and three variables, resp.). This design provides the best operating conditions of a model by reducing the number of trials when compared to the univariate process of optimization processes.

In this work of tomato dehydration by the adiabatic process of variables, the temperature, time, and thickness of the material were considered, as they make a relevant contribution to the physicochemical and sensorial features of tomato flour. The factor levels were coded as a central point $(0)$, factorial points $(-1,+1)$, and axial points. $(-\alpha,+\alpha)$. The results of the experiment were analyzed using the Statistica 11 software.

\section{Results and Discussion}

In any drying process, temperature and speed of vaporization depend on the water vapor concentration in the atmosphere $[32,33]$. During the conventional air-drying, setting heat and mass transfer results in the removal of moisture by thermal flow with the help of heated air, which flows across the fruit surface. Drying time is shorter with increasing temperatures [34]. Likewise, the temperature influences the process, and the pressure also affects the kinetics of each food type; thus, increasing temperatures reduce the drying time in all cases and this time is decreased further when the drying pressure reduces $[35,36]$. 
TABLE 1: Coded values and corresponding actual values used in the first experimental design.

\begin{tabular}{lccccc}
\hline \multirow{2}{*}{ Exploratory variable } & \multicolumn{5}{c}{ Level of variation } \\
& $-1.41(-\alpha)$ & -1 & 0 & 1 & $1.41(\alpha)$ \\
\hline Temperature $\left({ }^{\circ} \mathrm{C}\right)$ & 50 & 52.9 & 60 & 67.0 & 70 \\
Time $(\mathrm{h})$ & 10 & 15.82 & 30 & 44.18 & 50 \\
\hline
\end{tabular}

Many authors such as Olorunda et al. [37], Hawlader et al. [38], Baloch et al. [39], Shi et al. [40], Zanoni et al. [41], Giovanelli et al. [42], and Telis et al. [43] are dedicated to studying the parameters of drying process. For example, it has been proposed by Zanoni et al. [41] that modification of the operating conditions during air-drying of tomatoes, by using lower temperatures, reducing tomato sample thickness, and promoting partial removal of water (production of intermediate moisture tomatoes), can help to reduce oxidative damage in the final dried product. Another example is the use of osmotic dehydration, which has been suggested by some authors to yield good quality, fully dehydrated, or intermediate moisture products of improved stability [4447].

Akpinar et al. [48] and Movagharnejad and Nikzad [49] established factors that affect the drying speed and the processing time: food properties and secondary phenomena, linked to the necessity to limit the drying temperature, biophysical and biochemical transformations, and reduction caused by stress during dehydration and nonenzymatic browning reactions. Extreme temperatures and/or times in conventional air-drying can cause serious damage to product flavor, color, and nutrients and reduce the rehydration capacity of the dried product $[50,51]$. For example, under high temperatures considerable losses in ascorbic acid content have been reported during the production of dried tomato and tomato pulp $[41,42,52]$.

During the conventional air-drying, setting heat and mass transfer results in the removal of moisture by thermal flow with the help of heated air, which flows across the fruit surface. Drying time is shorter with increasing temperatures [34]. Likewise, the temperature influences the process, and the pressure also affects the kinetics of each food type. Thus, increasing temperatures reduce the drying time in all cases and this time is decreased further when the drying pressure reduces $[35,36]$.

In this experiment, the first variables studied were temperature and drying time, required to carry out the possible combinations of exploratory variables as the experimental design in Tables 1 and 2.

Temperature and time parameters were determined based on the effect of lower temperature in a shorter drying time to reach the final product humidity $<10 \%$. Temperatures below $50^{\circ} \mathrm{C}$ do not promote sufficient displacement of the water vapor from the material to reach the desired humidity and above $70^{\circ} \mathrm{C}$ volatilization of product components starts. The mass loss of the drying process was obtained by measuring a predetermined volume of product, at regular intervals. The range between the lowest and the highest values for each run was twofold, which demonstrate the importance of applying
TABLE 2: Central composite design (CCD) with observed response for mass loss (g).

\begin{tabular}{lccc}
\hline \multirow{2}{*}{ Run } & \multicolumn{2}{c}{ Exploratory variables } & Mass loss $(\mathrm{g})$ \\
& Temperature $\left({ }^{\circ} \mathrm{C}\right)$ & Time $(\mathrm{h})$ & 83.36 \\
1 & -1 & -1 & 104.67 \\
3 & 1 & -1 & 145.54 \\
4 & -1 & 1 & 146.73 \\
5 & 1 & 1 & 141.88 \\
6 & -1.41 & 0 & 146.24 \\
7 & 1.41 & 0 & 69.81 \\
8 & 0 & -1.41 & 146.36 \\
9 & 0 & 1.41 & 146.31 \\
10 & 0 & 0 & 146.28 \\
11 & 0 & 0 & 146.40 \\
12 & 0 & 0 & 146.22 \\
\hline
\end{tabular}

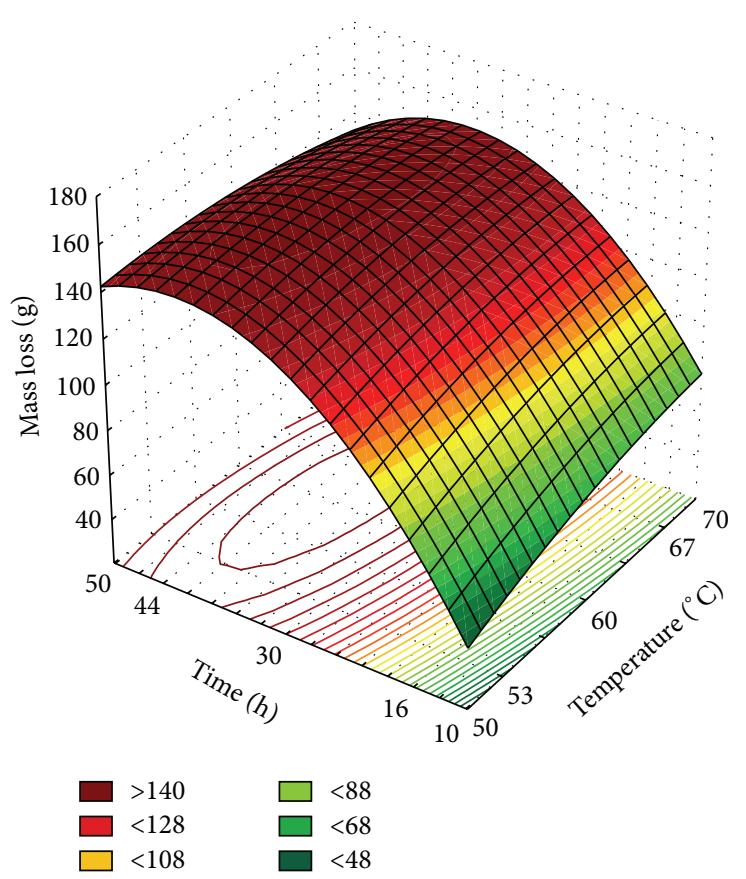

FIGURE 2: Surface response of tomato dehydration (time $\times$ temperature).

experimental design at this stage, when methods would take too much time. At the central point, higher intensity of mass loss was observed when compared to results from axial points (Table 2).

The experimental data was used to fit a mathematical model (2). The variance analysis of the regression is shown in Table 3 and adjusted surface response in Figure 2:

$$
\begin{aligned}
Y= & 146.32+3.5916 \times T-2.6146 \times T^{2}+26.601 \times T^{\prime} \\
& -20.7098 \times T^{\prime 2}-5.03 \times T \times T^{\prime},
\end{aligned}
$$


TABLE 3: Analysis of variance (ANOVA) for tomato mass loss subject to different times and temperatures during drying process.

\begin{tabular}{lcccc}
\hline FV & SQ & GL & MQ & $F$ \\
\hline Regression & 8584.553 & 5 & 1716.911 & 98.87475 \\
Residue & 104.187 & 6 & 17.3645 & \\
Lack of adjustment & 104.17 & 3 & 34.72333 & 6127.647 \\
Pure error & 0.017 & 3 & 0.005667 & \\
\hline Total & 8688.74 & 11 & & \\
\hline
\end{tabular}

TABLE 4: Coded values and corresponding actual values used in the second experimental design.

\begin{tabular}{lccccc}
\hline \multirow{2}{*}{ Exploratory variable } & \multicolumn{5}{c}{ Level of variation } \\
& -1.41 & -1 & 0 & 1 & 1.41 \\
\hline Temperatures $\left({ }^{\circ} \mathrm{C}\right)$ & 50 & 52.9 & 60 & 67.0 & 70 \\
Thickness $(\mathrm{mm})$ & 10 & 12.9 & 20 & 27.1 & 30 \\
\hline
\end{tabular}

where the regression equation coefficients are coefficients, $Y$ is the response in question (mass loss), and $T$ and $T^{\prime}$ are coded independent variables (temperature, time, resp.).

Taking into account the $F$ calculated higher than threefold $F$ tabulated (4.39) at a significance level of $5 \%$, it is possible to state that the model is predictive. Furthermore, either $R^{2}$ or adjusted $R^{2}$ were higher than 0.90 . The results shown in Figure 2 allow identifying the relationships between explanatory variables and the quantitative experimental response. The dimensional graph for optimization of tomato dehydration process indicated that the optimal conditions of dehydration process are between $35 \mathrm{~h}$ and $44 \mathrm{~h}$ at $52-67^{\circ} \mathrm{C}$. Therefore, the dehydration process of tomato by stationary system of adiabatic drying, with the factors, internal temperature of the drying chamber and retention time of the product inside the dryer, affects the quantification of the mass loss, represented by the amount of energy enough to evaporate water and remove water vapor from the product surface.

Another parameter studied was the relationship of temperature and tomato thickness. The results are shown in the experimental design (Tables 4 and 5), ANOVA (Table 6), and adjusted surface response (Figure 3 ).

The levels of temperature and tomato thickness were established to obtain the variation effect of the geometry of the material, considering the water movement from the inside to the surface of the product by the diffusion mechanism of the liquid and steam due to concentration gradients and temperature. The temperature variation was kept at the same range used in the previous experiment, $50-70^{\circ} \mathrm{C}$. For thickness, the axial points were considered as a limitation of the operating process (min. $10 \mathrm{~mm}$ and $\max .30 \mathrm{~mm}$ ).

The mass loss (Table 5) of the drying process was obtained by measuring the mass of a predetermined volume of the product until the final moisture content of $<10 \%$ was attained. The intensity of mass loss was similar among the combinations of the factors and a lower intensity was observed in a combination of variables $(1 ; 1),(-1 ; 1)$, and $(0 ; 1.41)$. Higher
TABLE 5: Central composite design (CCD) with observed response for tomato mass loss $(\mathrm{g})$.

\begin{tabular}{lccc}
\hline \multirow{2}{*}{ Test } & \multicolumn{2}{c}{ Exploratory variables } & Mass loss $(\mathrm{g})$ \\
\hline 1 & Temperature $\left({ }^{\circ} \mathrm{C}\right)$ & Thickness $(\mathrm{mm})$ & \\
2 & -1 & -1 & 145.59 \\
3 & 1 & -1 & 146.38 \\
4 & -1 & 1 & 129.42 \\
5 & 1 & 1 & 135.03 \\
6 & -1.41 & 0 & 145.22 \\
7 & 1.41 & 0 & 146.35 \\
8 & 0 & -1.41 & 146.35 \\
9 & 0 & 1.41 & 127.25 \\
10 & 0 & 0 & 146.34 \\
11 & 0 & 0 & 146.32 \\
12 & 0 & 0 & 146.31 \\
\hline
\end{tabular}

TABlE 6: Analysis of variance (ANOVA) for tomato mass loss subjected to different thickness and temperatures during drying process.

\begin{tabular}{lcccc}
\hline FV & SQ & GL & MQ & $F$ \\
\hline Regression & 567.242 & 5 & 113.4484 & 56.0551 \\
Residue & 12.14324 & 6 & 2.023873 & \\
Lack of adjustment & 12.1428 & 3 & 4.047587 & 25563.71 \\
Pure error & 0.0005 & 3 & 0.000158 & \\
\hline Total & 579.3853 & 11 & & \\
\hline
\end{tabular}

intensity mass loss was observed in the variables of the central point.

Adjusted mathematical model $\left(R^{2} 0.99\right)$ which predicts the effects of temperature and thickness variables and their interactions is

$$
\begin{aligned}
Y= & 146.34-6.82 \times T-5.34 \times T^{2}+1.00 \times T^{\prime \prime}-0.82 \\
& \times T^{\prime \prime 2}+1.2050 \times T \times T^{\prime \prime},
\end{aligned}
$$

where the regression equation coefficients are coefficients, $Y$ is the response in question (mass loss), and $T$ and $T^{\prime \prime}$ are coded independent variables (temperature, thickness, resp.).

In the ANOVA, as the $F$ calculated for regression was much greater than the tabulated $F(4.39)$ at a significance level of $5 \%$, it is concluded that the mathematical model is valid and also can be used for predictive purposes (Table 6).

The surface response showed in Figure 3 indicates the mass loss under the temperature and thickness range applied in drying process of tomatoes. It shows that it is possible to reach the ideal conditions of range of $15-27 \mathrm{~mm}$ thickness under $53-58^{\circ} \mathrm{C}$, results in accordance with the temperature range for the previous experiment where the variables were temperature $\times$ time.

In addition to the interactions between two variables, the experiment for the three variables together was performed, thereby obtaining the data for the experimental design (Tables 7 and 8), ANOVA (Table 9), and surface response (Figure 4). 


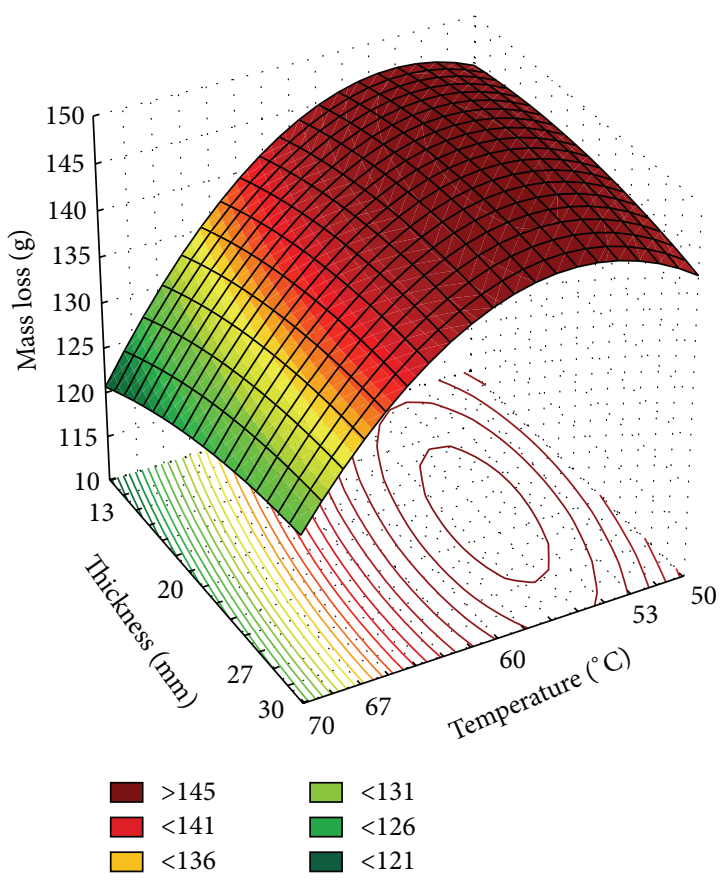

Figure 3: Response surface to tomato dehydration (thickness $\times$ temperature).

TABLE 7: Coded values and corresponding actual values used in the third experimental design.

\begin{tabular}{lccccc}
\hline \multirow{2}{*}{ Exploratory variable } & \multicolumn{5}{c}{ Level of variation } \\
& -1.68 & -1 & 0 & 1 & 1.68 \\
\hline Thickness & 10 & 12.9 & 20 & 27.1 & 30 \\
Time & 10 & 15.82 & 30 & 44.18 & 50 \\
Temperature & 50 & 52.9 & 60 & 67.0 & 70 \\
\hline
\end{tabular}

The data in Table 8 indicate that, when related to axial variables of time $(10 \mathrm{~h}$ and $50 \mathrm{~h}$ ) and the central points for thickness and temperature, water loss was significantly lower than the other combinations. At extreme low time, there was no effective removal of water vapor from the product surface and at the extreme high time, limits of the thermal flow were exceeded in the moisture removal in the kinetics of tomato dehydration.

The adjusted mathematical model $\left(R^{2} 0.99\right)$ is presented in the following equation:

$$
\begin{aligned}
Y= & 145.61-8.62 \times T^{\prime \prime}-3.37 \times T^{\prime \prime 2}+9.85 \times T^{\prime} \\
& -11.42 \times T^{\prime 2}+2.06 \times T+1.33 \times T^{2}-0.05 \times T^{\prime \prime} \\
& \times T^{\prime}+2.10 \times T^{\prime \prime} \times T-0.165 \times T^{\prime} \times T,
\end{aligned}
$$

where the regression equation coefficients are coefficients, $Y$ is the response in question (mass loss), and $T, T^{\prime}$, and $T^{\prime \prime}$ are coded independent variables (temperature, time, and thickness, resp.).

Table 9 shows that although the model is valid, regression is not predictive, because the $F$ value of the regression was not three times greater than the $F_{\text {critical }}$ value (3.23).

\begin{tabular}{|c|c|c|c|c|}
\hline \multirow{2}{*}{ Test } & \multicolumn{3}{|c|}{ Exploratory variables } & \multirow{2}{*}{ Mass loss $(\mathrm{g})$} \\
\hline & Thickness & Time & Temperature & \\
\hline 1 & -1 & -1 & -1 & 143.85 \\
\hline 2 & 1 & -1 & -1 & 130.92 \\
\hline 3 & -1 & 1 & -1 & 145.59 \\
\hline 4 & 1 & 1 & -1 & 122.8 \\
\hline 5 & -1 & -1 & 1 & 144.97 \\
\hline 6 & 1 & -1 & 1 & 130.8 \\
\hline 7 & -1 & 1 & 1 & 136.39 \\
\hline 8 & 1 & 1 & 1 & 131.68 \\
\hline 9 & -1.68 & 0 & 0 & 143.62 \\
\hline 10 & 1.68 & 0 & 0 & 127.99 \\
\hline 11 & 0 & -1.68 & 0 & 69.81 \\
\hline 12 & 0 & 1.68 & 0 & 81.36 \\
\hline 13 & 0 & 0 & -1.68 & 141.88 \\
\hline 14 & 0 & 0 & 1.68 & 146.31 \\
\hline 15 & 0 & 0 & 0 & 146.31 \\
\hline 16 & 0 & 0 & 0 & 146.29 \\
\hline 17 & 0 & 0 & 0 & 146.25 \\
\hline 18 & 0 & 0 & 0 & 146.2 \\
\hline
\end{tabular}

TABLE 8: Box-Behnken design with observed response for tomato mass loss (g).

TABLE 9: Analysis of variance (ANOVA) for tomato mass loss during drying process.

\begin{tabular}{lcccc}
\hline FV & SQ & GL & MQ & $F$ \\
\hline Regression & 6975.588 & 8 & 871.9485 & 5.94 \\
Residue & 1320.81 & 9 & 146.7567 & \\
Lack of adjustment & 1320.803 & 6 & 220.1339 & 93343.0 \\
Pure error & 0.007 & 3 & 0.002358 & \\
\hline Total & 8296.398 & 17 & & \\
\hline
\end{tabular}

In this model, Box-Behnken design was applied. The three levels of factors, temperature, thickness, and time, fixing the temperature variation level at 0 and applying a factorial $2^{2}$ with the other two variables, were considered. Figure 4 shows that at fixed temperature of $60^{\circ} \mathrm{C}$ it is possible to use less thick tomato slices to obtain dried samples in a shorter time, optimizing the process. The temperature of $60^{\circ} \mathrm{C}$ is viable, since any temperature below this limit cannot effectively remove water, and temperatures above promote the abrupt removal of water causing a possible mischaracterization of the product.

\section{Conclusion}

The tomato powder, as well as most dehydrated foods, should be produced under controlled operating conditions, because the quality of the final product depends on several factors related to the variables of the dehydration process. Thus, the market for dried tomato has increasingly demanded better quality products, which has led to several studies on the matter. 


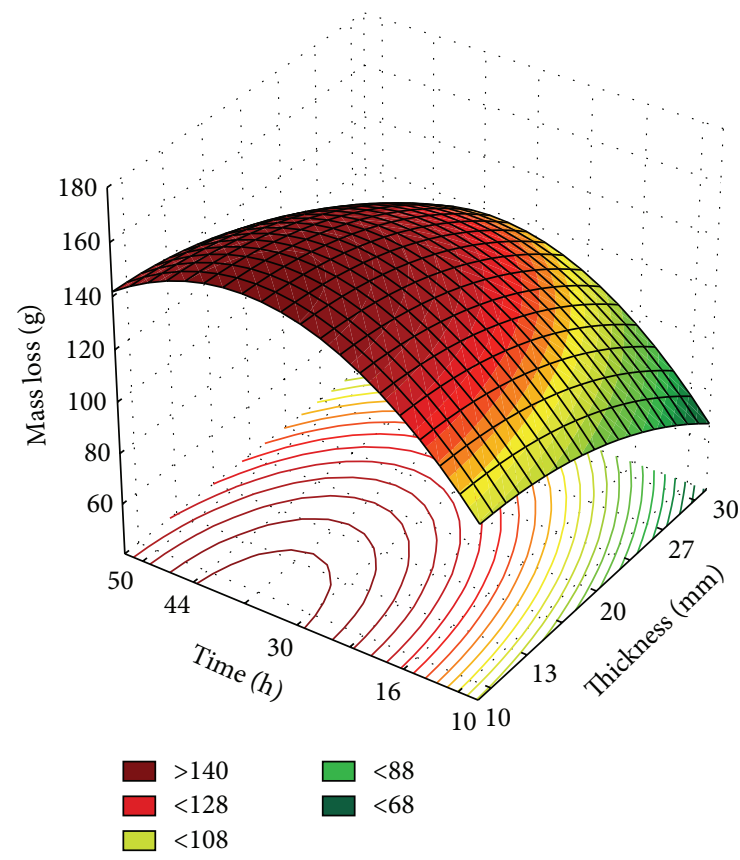

FIGURE 4: Response surface for tomato dehydration fixing the temperature variation level at $60^{\circ} \mathrm{C}$.

The models of adiabatic drying of tomatoes were predictive, as they showed $R^{2}$ above 0.7 and when subjected to the analysis of variance, except for the last adjusted model, which requires further studies for its validation. Optimal conditions in the dehydration process were $35-44 \mathrm{~h}$ at $52-67^{\circ} \mathrm{C}$ with tomato slices between 15 and $27 \mathrm{~mm}$ thickness. When the temperature is adjusted at $60^{\circ} \mathrm{C}$, a thinner slice of tomato can be used, reducing the processing time.

\section{Practical Application}

The practical application is to study the drying process to optimize the dehydration process for tomatoes fruits.

\section{Conflict of Interests}

The authors declare that there is no conflict of interests regarding the publication of this paper.

\section{References}

[1] K. Sacilik, "The thin-layer modelling of tomato drying process," Agriculturae Conspectus Scientificus, vol. 72, no. 4, pp. 343-349, 2007.

[2] J. S. de Souza, Estudo da desidratação do tomate (Lycopersicon esculentum Mill) em pedaços com pré- tratamento osmótico [Dissertação Programa de pós-graduação em Engenharia Química], Universidade Federal do Rio Grande do Norte, Natal, Brazil, 2002.

[3] S. Georgé, F. Tourniaire, H. Gautier, P. Goupy, E. Rock, and C. Caris-Veyrat, "Changes in the contents of carotenoids, phenolic compounds and vitamin $\mathrm{C}$ during technical processing and lyophilisation of red and yellow tomatoes," Food Chemistry, vol. 124, no. 4, pp. 1603-1611, 2011.

[4] A. A. Kader, "Postharvest biology and technology: an overview," in Postharvest Technology of Horticultural Crops, A. A. Kader, Ed., Publication 3311, pp. 15-20, Division of Agriculture and Natural Resources, University of California, Oakland, Calif, USA, 1992.

[5] O. C. Aworth and A. O. Olorunda, "Towards reducing postharvest losses of perishable fruits and vegetables in Nigeria," in Proceedings of the National Conference in Agriculture, Port Harcourt, Nigeria, 1981.

[6] J. Shi and M. Le Maguer, "Lycopene in tomatoes: chemical and physical properties affected by food processing," Critical Reviews in Food Science and Nutrition, vol. 40, no. 1, pp. 1-42, 2000.

[7] F. Khachik, L. Carvalho, P. S. Bernstein, G. J. Muir, D.-Y. Zhao, and N. B. Katz, "Chemistry, distribution, and metabolism of tomato carotenoids and their impact on human health," Experimental Biology and Medicine, vol. 227, no. 10, pp. 845-851, 2002.

[8] J. A. Vinson, Y. Hao, X. Su, and L. Zubik, "Phenol antioxidant quantity and quality in foods: vegetables," Journal of Agricultural and Food Chemistry, vol. 46, no. 9, pp. 3630-3634, 1998.

[9] Embrapa, Tomate Para Processamento Industrial, Embrapa Comunicação para Transferência de Tecnologia/Embrapa Hortaliças, Brasília, Brazil, 2000.

[10] EMBRAPA, Cultivo do tomate para industrialização, 2006, http://sistemasdeproducao.cnptia.embrapa.br/FontesHTML/Tomate/TomateIndustrial_2ed/composicao.htm\#tabelal.

[11] G. C. R. M. Andrade, M. Oetterer, and V. L. Tornisielo, "O tomate-cadeia produtiva e resíduos de agrotóxicos," Revista Ecotoxicologia e Meio Ambiente, vol. 20, pp. 57-66, 2010.

[12] P. J. Fellows, Food Processing Technology, Woodhead Publishing Limited and CRC Press, Boca Raton, Fla, USA, 3rd edition, 2009.

[13] M. K. Krokida, V. T. Karathanos, Z. B. Maroulis, and D. Marinos-Kouris, "Drying kinetics of some vegetables," Journal of Food Engineering, vol. 59, no. 4, pp. 391-403, 2003.

[14] C. T. Kiranoudis, Z. B. Maroulis, E. Tsami, and D. MarinosKouris, "Drying kinetics of some fruits," Drying Technology, vol. 15, no. 5, pp. 1399-1418, 1997.

[15] C. T. Akanbi and F. O. Oludemi, "Effect of processing and packaging on the lycopene content of tomato products," International Journal of Food Properties, vol. 7, no. 1, pp. 139-152, 2004.

[16] I. Doymaz, "Air-drying characteristics of tomatoes," Journal of Food Engineering, vol. 78, no. 4, pp. 1291-1297, 2007.

[17] M. S. Brooks, N. H. Abou El-Hana, and A. E. Ghaly, "Effects of tomato geometries and air temperature on the drying behavior of plum tomato," The American Journal of Applied Sciences, vol. 5, no. 10, pp. 1369-1375, 2008.

[18] C. T. Akanbi, R. S. Adeyemi, and A. Ojo, "Drying characteristics and sorption isotherm of tomato slices," Journal of Food Engineering, vol. 73, no. 2, pp. 157-163, 2006.

[19] M. Maskan, "Microwave/air and microwave finish drying of banana," Journal of Food Engineering, vol. 44, no. 2, pp. 71-78, 2000.

[20] E. S. Alessi, Tomate seco obtido por energia solar e convencional a partir de mini-tomates congelados [M.S. thesis], Escola Superior de Agricultura Luiz de Queiroz, Universidade de São Paulo, São Paulo, Brazil, 2010. 
[21] G. A. Camargo, Secagem de tomate (Lycopersicon esculentium Mill) para conserva: estudos de parâmetros com base na qualidade final [M.S. thesis], Faculdade de Engenharia Agrícola da Universidade Estadual de Campinas, Campinas, Brazil, 2000.

[22] I. Verlent, M. Hendrickx, P. Rovere, P. Moldenaers, and A. Van Loey, "Rheological properties of tomato-based products after thermal and high-pressure treatment," Journal of Food Science, vol. 71, no. 3, pp. S243-S248, 2006.

[23] M. G. Davoodi, P. Vijayanand, S. G. Kulkarni, and K. V. R. Ramana, "Effect of different pre-treatments and dehydration methods on quality characteristics and storage stability of tomato powder," LWT-Food Science and Technology, vol. 40, no. 10, pp. 1832-1840, 2007.

[24] S. Pereira, Processamento de tomate (Lycopersicon esculentum Mill), cv. Debora cultivados de forma tradicional e orgânica, para obtenção de extrato [Dissertação-Mestrado em Ciências e Tecnologia dos Alimentos], Universidade Federal Rural do Rio de Janeiro, 2007.

[25] G. Muratore, V. Rizzo, F. Licciardello, and E. Maccarone, "Partial dehydration of cherry tomato at different temperature, and nutritional quality of the products," Food Chemistry, vol. 111, no. 4, pp. 887-891, 2008.

[26] C. Gärtner, W. Stahl, and H. Sies, "Lycopene is more bioavailable from tomato paste than from fresh tomatoes," The American Journal of Clinical Nutrition, vol. 66, no. 1, pp. 116-122, 1997.

[27] W. Stahl and H. Sies, "Uptake of lycopene and its geometrical isomers is greater from heat-processed than from unprocessed tomato juice in humans," Journal of Nutrition, vol. 122, no. 11, pp. 2161-2166, 1992.

[28] P. Pani, A. A. Leva, M. Riva, A. Maestrelli, and D. Torreggiani, "Influence of an osmotic pre-treatment on structure-property relationships of air-dehydrated tomato slices," Journal of Food Engineering, vol. 86, no. 1, pp. 105-112, 2008.

[29] J. G. Brennan, "Water activity and food quality," in Food Dehydration: A Dictionary and Guide, G. Campbell-Platt, Ed., pp. 129-131, Butterworth-Heinemann, Boston, Mass, USA, 1994.

[30] V. Lavelli, B. Zanoni, and A. Zaniboni, "Effect of water activity on carotenoid degradation in dehydrated carrots," Food Chemistry, vol. 104, no. 4, pp. 1705-1711, 2007.

[31] S. Rahman, "Water activity and sorption properties of food," in Food Properties Handbook, F. M. Clydesdale, Ed., pp. 1-83, CRC Press, Boca Raton, Fla, USA, 1995.

[32] P. P. Lewicki, "Design of hot air drying for better foods," Trends in Food Science \& Technology, vol. 17, no. 4, pp. 153-163, 2006.

[33] S. Simal, A. Femenía, P. Llull, and C. Rosselló, "Dehydration of aloe vera: simulation of drying curves and evaluation of functional properties," Journal of Food Engineering, vol. 43, no. 2, pp. 109-114, 2000.

[34] S. M. Pokharkar, S. Prasad, and H. Das, "A model for osmotic concentration of banana slices," Journal of Food Science and Technology, vol. 34, no. 3, pp. 230-232, 1997.

[35] S. Damodaran, K. L. Parkin, and O. R. Fennema, Química de Alimentos de Fennema, Artmed, 2010.

[36] D. A. Blackadder, Manual de Operações Unitárias, Hemus, São Paulo, Brazil, 2004.

[37] A. O. Olorunda, O. C. Aworh, and C. N. Onuoha, "Upgrading quality of dried tomato: effects of drying methods, conditions and pre-drying treatments," Journal of the Science of Food and Agriculture, vol. 52, no. 4, pp. 447-454, 1990.

[38] M. N. A. Hawlader, M. S. Uddin, J. C. Ho, and A. B. W. Teng, "Drying characteristics of tomatoes," Journal of Food Engineering, vol. 14, no. 4, pp. 259-268, 1991.
[39] W. A. Baloch, S. Khan, and A. K. Baloch, "Influence of chemical additives on the stability of dried tomato powder," International Journal of Food Science and Technology, vol. 32, no. 2, pp. 117120, 1997.

[40] J. Shi, M. L. Maguer, Y. Kakuda, A. Liptay, and F. Niekamp, "Lycopene degradation and isomerization in tomato dehydration," Food Research International, vol. 32, no. 1, pp. 15-21, 1999.

[41] B. Zanoni, C. Peri, R. Nani, and V. Lavelli, "Oxidative heat damage of tomato halves as affected by drying," Food Research International, vol. 31, no. 5, pp. 395-401, 1998.

[42] G. Giovanelli, B. Zanoni, V. Lavelli, and R. Nani, "Water sorption, drying and antioxidant properties of dried tomato products," Journal of Food Engineering, vol. 52, no. 2, pp. 135141, 2002.

[43] V. R. N. Telis, R. C. B. D. L. Murari, and F. Yamashita, "Diffusion coefficients during osmotic dehydration of tomatoes in ternary solutions," Journal of Food Engineering, vol. 61, no. 2, pp. 253259, 2004.

[44] C. A. Alvarez, R. Aguerre, R. Gómez, S. Vidales, S. M. Alzamora, and L. N. Gerschenson, "Air dehydration of strawberries: effects of blanching and osmotic pretreatments on the kinetics of moisture transport," Journal of Food Engineering, vol. 25, no. 2, pp. 167-178, 1995.

[45] A. Nieto, D. Salvatori, M. A. Castro, and S. M. Alzamora, "Air drying behavior of apples as affected by blanching and glucose impregnation," Journal of Food Engineering, vol. 36, no. 1-4, pp. 63-79, 1998.

[46] F. Nsonzi and H. S. Ramaswamy, "Quality evaluation of osmoconvective dried blueberries," Drying Technology, vol. 16, no. 35, pp. 705-723, 1998.

[47] C. K. Sankat, F. Castaigne, and R. Maharaj, "The air drying behaviour of fresh and osmotically dehydrated banana slices," International Journal of Food Science and Technology, vol. 31, no. 2, pp. 123-135, 1996.

[48] E. K. Akpinar, Y. Bicer, and C. Yildiz, "Thin layer drying of red pepper," Journal of Food Engineering, vol. 59, no. 1, pp. 99-104, 2003.

[49] K. Movagharnejad and M. Nikzad, "Modeling of tomato drying using artificial neural network," Computers and Electronics in Agriculture, vol. 59, no. 1-2, pp. 78-85, 2007.

[50] T. M. Lin, T. D. Durance, and C. H. Scaman, "Characterization of vacuum microwave, air and freeze dried carrot slices," Food Research International, vol. 31, no. 2, pp. 111-117, 1998.

[51] A. E. Drouzas, E. Tsami, and G. D. Saravacos, "Microwave/ vacuum drying of model fruit gels," Journal of Food Engineering, vol. 39, no. 2, pp. 117-122, 1999.

[52] V. Dewanto, X. Z. Wu, K. K. Adom, and R. H. Liu, “Thermal processing enhances the nutritional value of tomatoes by increasing total antioxidant activity," Journal of Agricultural and Food Chemistry, vol. 50, no. 10, pp. 3010-3014, 2002. 

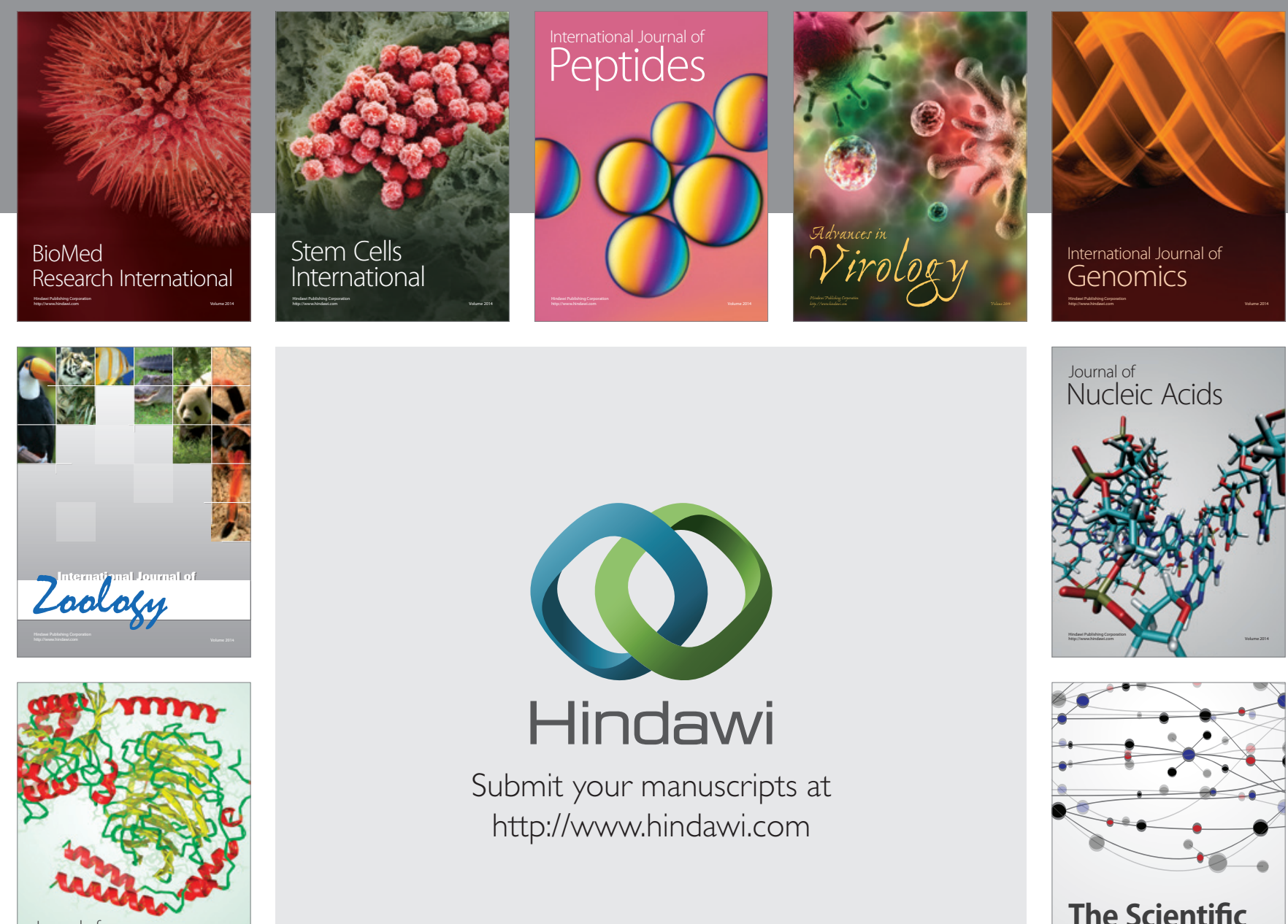

Submit your manuscripts at

http://www.hindawi.com

Journal of
Signal Transduction
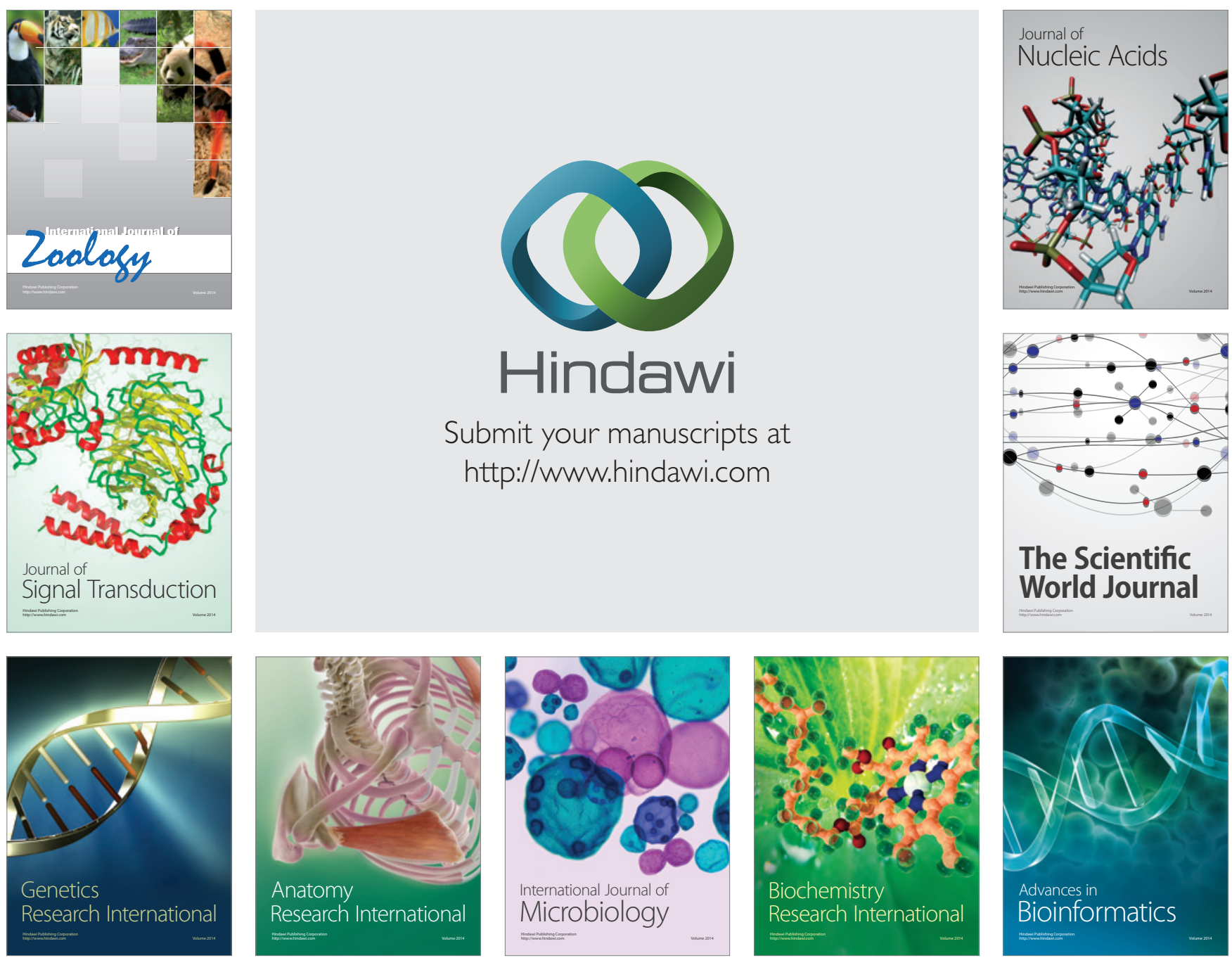

The Scientific World Journal
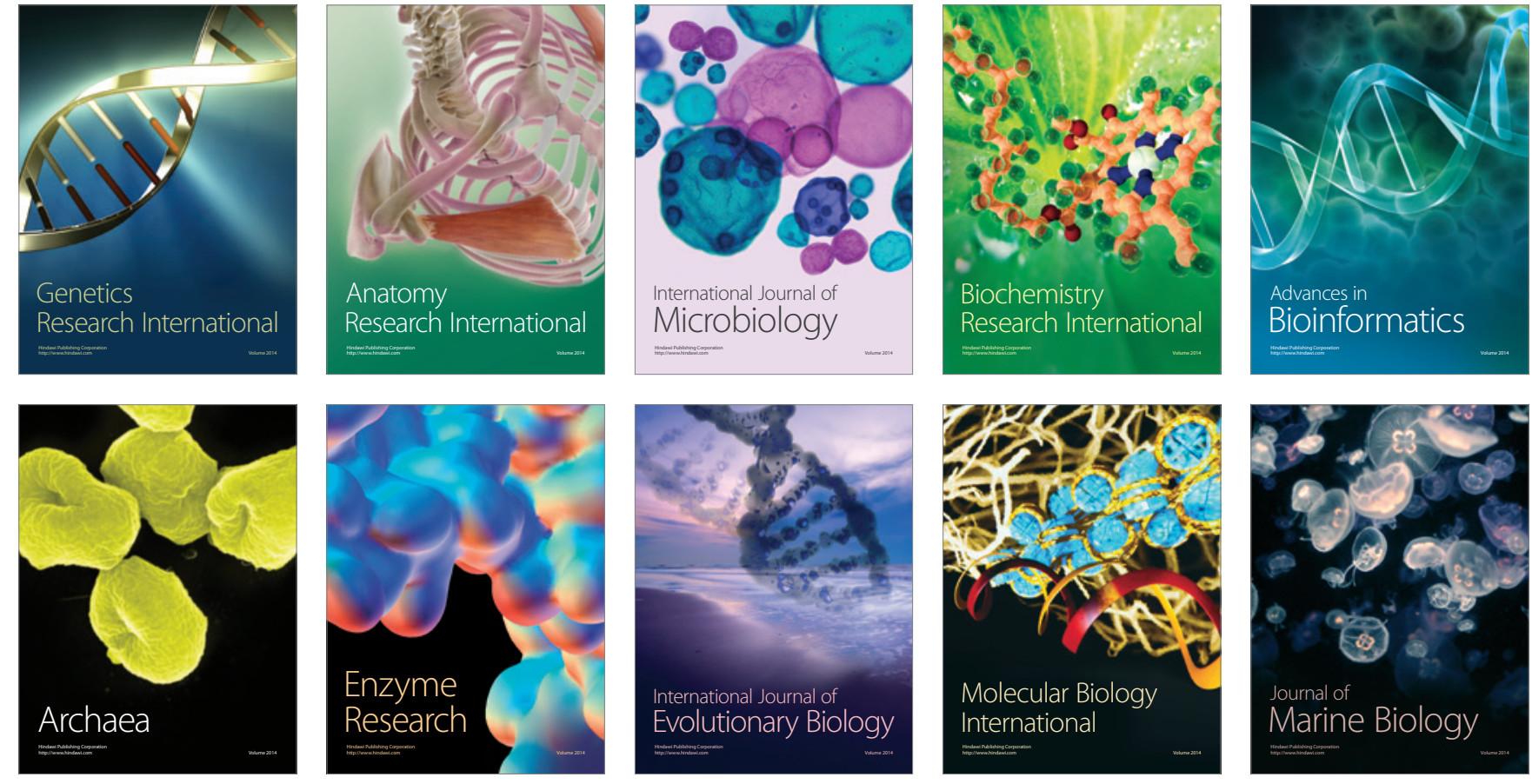